\title{
Phytoplankton abundance, community structure and diversity in the eutrophicated Orbetello lagoon (Tuscany) from 1995 to 2001
}

\section{Abondance du phytoplancton, structure des communautés et diversité dans la lagune eutrophisée d'Orbetello (Toscane) de 1995 à 2001}

\author{
Caterina Nuccio *, Chiara Melillo, Luca Massi, Mario Innamorati \\ Laboratorio di Ecologia, Dipartimento di Biologia vegetale, Università di Firenze, Via P.A. Micheli, 1, 50121 Florence, Italy
}

Received 31 July 2002; revised and accepted 30 September 2002

\begin{abstract}
The Orbetello lagoon consists of two coastal ponds, Laguna di Ponente and Laguna di Levante, characterized by high nutrient concentrations, very poor exchanges with the sea and subjected to recurrent eutrophication crisis mainly in the past decades. To assess its current trophic status, from 1995 to 2001 the temporal evolution and spatial distribution of environmental factors, phytoplankton biomass and composition have been investigated. In this paper, the mean annual cycles of phytoplankton abundance, community structure and diversity are discussed. The seasonal cycles of micro- and nanophytoplankton densities are characterized by high frequency oscillations with fast increasing and decreasing blooms, but generally the lowest densities occur in winter, except for the peaks of December, and the highest ones during spring and summer. Despite the variability at short time scale of phytoplankton density, composition and diversity, a recurrent pattern was evidenced. Nanoplanktonic flagellates were the dominant fraction, mainly cryptophyceans during winter and early spring, while diatoms showed high summer blooms of nanoplanktonic centric genera and were very scarce during the other seasons, mainly with pennate genera. The phytoplankton community structure appeared to be more diversified from early summer to fall with the variable contribution of diatoms, dinoflagellates and other flagellates. Phytoplankton diversity, computed by means of the Shannon index, was relatively low (mean of 1.96 bit per cell) and two phases, common to the whole lagoon, have been evidenced: a first phase of lower diversity during winter and early spring, followed by an increasing trend that reached the highest diversity in late summer-fall. The pattern of nutrients' (DIN and DIP) availability and depletion leads to a seasonal change of the N/P ratio that seems to play a role as regards the phytoplankton community succession and then diversity, favoring or limiting the growth of the different groups.
\end{abstract}

(c) 2003 Éditions scientifiques et médicales Elsevier SAS. All rights reserved.

\section{Résumé}

La lagune d'Orbetello est formée de deux étendues d'eau côtières, la lagune du Ponent et la lagune du Levant caractérisées par des concentrations élevées de sels nutritifs, de faibles échanges avec la mer et soumises à des crises dystrophiques récurrentes dans les dernières décennies. Pour connaître son état trophique, l'évolution spatiale et temporelle des facteurs de l'environnement, de la biomasse et de la composition phytoplanctonique a été suivie de 1995 à 2001. Cet article présente les cycles annuels moyens de l'abondance du phytoplancton, de la structure des communautés et de la diversité. Les variations saisonnières du micro- et du nanophytoplancton présentent des oscillations à haute fréquence avec des floraisons apparaissant puis disparaissant rapidement. Généralement, les densités les plus faibles apparaissent en hiver, à l'exception de pics en décembre, et les plus élevées au printemps et en été. Malgré la variabilité haute fréquence, un schéma d'organisation peut être mis en évidence. Les flagellés nanoplanctoniques constituent la fraction dominante, principalement les cryptophycées, durant l'hiver et au début du printemps tandis que les diatomées sont à l'origine de floraisons importantes en été ; le reste de l'année, elles sont rares, le groupe des pennés dominant alors. La communauté phytoplanctonique est plus diversifiée du début de l'été à l'automne avec des contributions variables des diatomées, des dinoflagellés et autres flagellés. La diversité du phytoplancton, exprimée par l'indice de Shannon, est relativement basse (en moyenne 1.96 bit cell $^{-1}$ ) et deux phases, communes à l'ensemble de la lagune, sont mises en lumière : la première de basse diversité en hiver et au début du printemps, suivie d'un accroissement qui atteint un pic en fin d'été et à l'automne. La distribution des

* Corresponding author.

E-mail address: catnuccio@unifi.it (C. Nuccio). 
sels nutritifs (azote inorganique dissous et phosphore inorganique dissous) souligne un changement saisonnier du rapport N/P qui paraît jouer un rôle sur la succession des espèces et donc la diversité favorisant ou limitant la croissance de tel ou tel groupe.

(C) 2003 Éditions scientifiques et médicales Elsevier SAS. Tous droits réservés.

Keywords: Phytoplankton community structure; Phytoplankton diversity; Orbetello Lagoon; N/P ratio

Mots clés : Communauté phytoplanctonique ; Diversité du phytoplancton ; Lagune d'Orbetello ; Taux N/P

\section{Introduction}

Coastal lagoons are in many cases eutrophic or hypertrophic environments receiving high nutrient inputs from anthropogenic sources and of autochthonous origin that sustain high level of primary production, both benthic and planktonic. Their environmental features (shallow waters, strong seasonal gradient of temperature and salinity, wind or tidal effects) deal with high variability at short spatial and temporal scales of the communities (Carrada and Fresi, 1988).

The Orbetello lagoon is a coastal pond characterized by very poor exchange with the sea waters and subjected to recurrent eutrophication and anoxic crisis mainly since the 1960s because of the economic and touristic development of the area, followed by the increment of urban, agricultural and fish-farm wastewaters (Innamorati, 1998). Some remedial activities, like seawater pumping and seaweeds harvesting (Lenzi, 1992), have been carried out and intensified after the last distrophic crisis occurred in 1993.

With the aim to assess the current trophic status of the lagoon, from 1995 to 2001 a long time series with high frequency measurements and sampling of environmental and biological variables (physical factors, nutrients, phytoplankton biomass and composition) has been carried out (Cartei et al., 1998; Innamorati, 1998; Innamorati et al., 2000; Innamorati et al., 2001). The main results show the eutrophic conditions of the waters with high level of nutrients, organic matter and phytoplankton biomass and high variability at short temporal scale. However, there is evidence of a recognizable seasonal pattern with a relative spatial and temporal homogeneity in the whole lagoon. Variables like temperature, salinity, dissolved oxygen and inorganic nutrients, even with different ranges of variation, showed recurrent and synchronous fluctuations in the different sites of the lagoon (Innamorati et al., 2000). As evidenced by the spectral analysis (Innamorati et al., 2001), despite the more complex shape of the variance spectra of the biological variables, there is clear evidence that all the variables showed an unimodal annual cycle, therefore, controlled by meteoclimatic factors. However, analyzing the spatial distribution on a more detailed grid of 23 stations (Cartei et al., 1998; Innamorati, 1998), the anthropogenic disturbances appeared to affect the lagoon at a short spatial scale while the most important contribution of nutrients originated from the sediments and were induced by the microbial activity with a seasonal regular pattern.

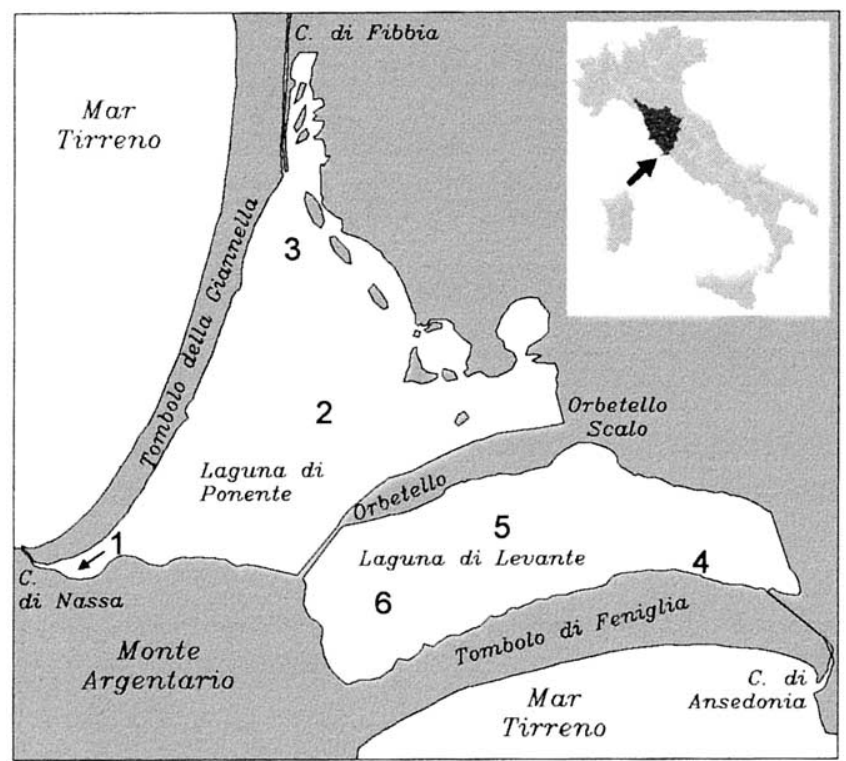

Fig. 1. Map of the Orbetello lagoon and sampling sites.

To characterize the phytoplankton community and its temporal evolution, the diversity has been evaluated by means of the Shannon index. This synthetic index can give information about the community structure and it can be used for a synthetic comparison between different environments, as showed in Innamorati et al. (1996). In this study, the evaluation of the diversity highlighted the difference between the communities of oligotrophic and eutrophic seawaters showing the higher equitability reached by the oligotrophic community as regards eutrophic one.

In this paper, the temporal variation of phytoplankton abundance, community structure and diversity in the Orbetello lagoon has been analyzed as a first approach to assess the general features of phytoplankton succession and diversity. Moreover, the relationships between its development and the variation of environmental factors, mainly nutrients, have been investigated.

\section{Material and methods}

The Orbetello lagoon Fig. 1 covers an area of 2700 ha along the southern Tuscany coast (central Italy). It consists of two ponds about $1 \mathrm{~m}$ deep, communicating with the Tyrrhenian sea waters by means of two long and narrow canals: Nassa (NW) and Ansedonia (SE) in the Laguna di Ponente 
and Laguna di Levante, respectively. From September 1995 to October 2001, with an interruption between October 1997 and May 1998, fortnightly surveys were carried out on six stations. The six stations Fig. 1 were chosen to characterize the spatial variability of the environmental factors in the two ponds: st. 1 is close to the canal of Nassa and st. 4 to the canal of Ansedonia; st. 2 and 5 are situated in the middle of each basin, st. 3 receives the waters of the river Albegna through the canal of Fibbia, st. 6 is located in the inner west side of the Laguna di Levante.

At each station physical, chemical and biological parameters were determined following standard methods (Innamorati et al., 1990). In this paper data of DIN (nitrates plus nitrites plus ammonia), DIP (orthophosphates), phytoplankton biomass (chloropheopigments), density and diversity were discussed. The term chloropheopigments used later on refers to the spectrophotometric equation of Jeffrey and Humphrey (1975) modified by Innamorati et al. (1994).

Microscopy countings of micro- and nanophytoplankton were performed on 525 samples $(250 \mathrm{ml})$ collected at the depth of $30 \mathrm{~cm}$ of the six stations. Samples were fixed with neutralized formalin to the final concentration of 3\% formaldehyde and examined with inverted microscopes (Zeiss IM35, Zeiss IM, Nikon Diaphot, magnification 400×) after sedimentation (Zingone et al., 1990) of a subsample of $25 \mathrm{ml}$. For taxonomic identification the following texts were used: Schiller, 1931-1937; Butcher, 1967; Cupp, 1977; Sournia, 1986; Hasle and Syvertsen, 1997; Heimdal, 1997; Steidinger and Tangen, 1997; Throndsen, 1997. Phytoplankton diversity was computed with Shannon index for each examined sample, computing as separate entities the taxa undetermined at the species level but distinguished on the basis of their morphological and dimensional features. The phytoplankton countings, in the settled subsample of $25 \mathrm{ml}$, were carried out up to the plateau of the relationship between the counted species and the observed volume.

\section{Results}

With regard to the trophic conditions of the lagoon, inorganic nitrogen (DIN) and phosphorus (DIP) covered a wide range of concentrations (from 0.5 to $70 \mu \mathrm{M}$ DIN, from undetectable values to $1.6 \mu \mathrm{M}$ DIP) and followed an evident unimodal seasonal variation, synchronous in the six sites analyzed, as showed by their mean annual cycles Fig. 2. DIN and DIP concentrations exhibit an opposite trend with winter maxima of the former and summer maxima of the latter. This kind of fluctuation leads to a consequent seasonal variation of the N/P ratio in the lagoon waters Fig. 3 in which the lowest values occur in summer, while the highest ones in winter.

Phytoplankton biomass too, as chloropheopigment concentrations, had wide variations from less of 0.5 up to about $66 \mathrm{mg} \mathrm{m}^{-3}$ with a slightly higher mean in the Laguna di Levante $\left(7 \mathrm{mg} \mathrm{m}^{-3}\right)$ than in the Laguna di Ponente $\left(5.6 \mathrm{mg} \mathrm{m}^{-3}\right)$. From the mean annual cycles Fig. 4 any
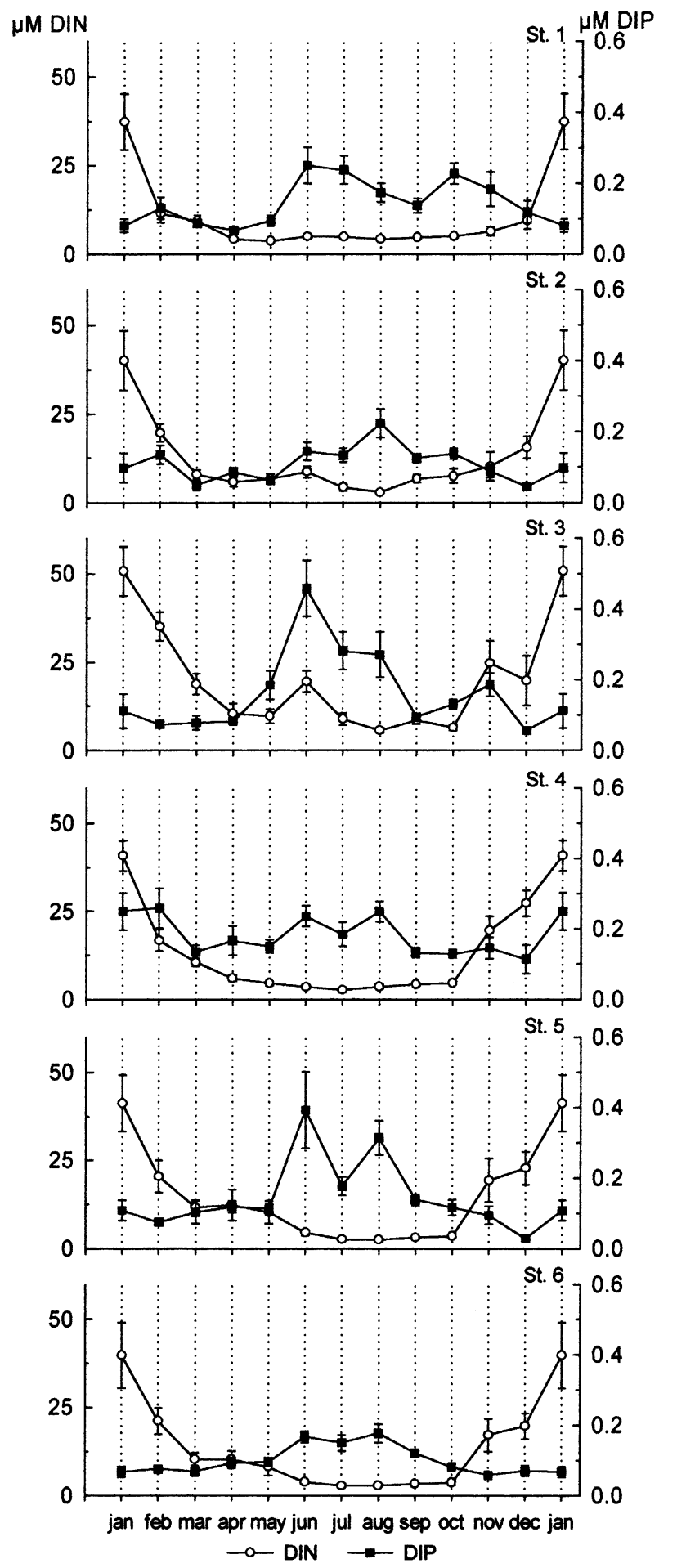

Fig. 2. DIN (nitrates plus nitrites plus ammonia) and DIP (orthophosohates) concentrations $(\mu \mathrm{M})$ in the six stations: monthly mean + S.E.

regular and common trend did not seem to appear in the six stations. It was maxima both in winter and in summer, at st. 1 there were the smallest oscillations between minima and maxima while in the Laguna di Levante there was the highest variability. 


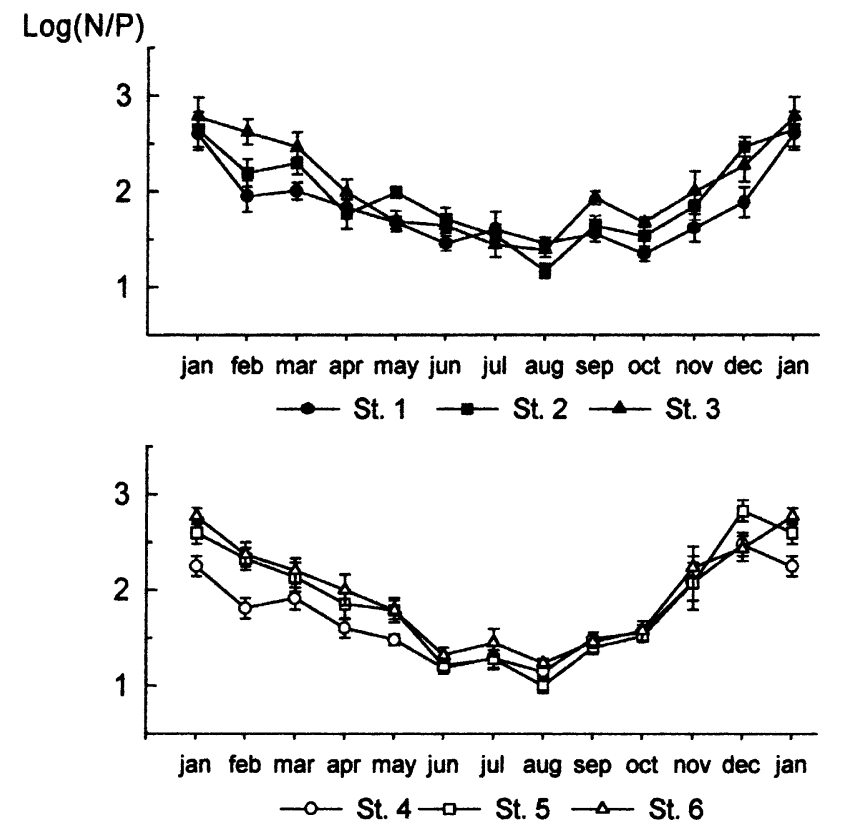

Fig. 3. Log of the N/P ratio in the six stations $(\mathrm{N}=$ nitrates plus nitrites plus ammonia; $\mathrm{P}=$ orthophosohates): monthly mean + S.E.

The interannual variation of the phytoplankton total densities Fig. 5 ranged between two orders of magnitude, from the winter minima of less than $0.1 \times 10^{6}$ to more than $8 \times 10^{6}$ cells per 1 of some summer peaks (up to $10 \times 10^{6}$ cells per 1 in July 1998 at st. 4). The densities showed oscillations at a fortnightly scale, mainly in the Laguna di Levante (st. 4 and 5 ) where mean density was slightly higher than in the Laguna di Ponente, $1.3 \times 10^{6}$ and $0.84 \times 10^{6}$ cells per 1 , respectively. The most recurrent periods of increase took place from late spring to summer, when the highest peaks occurred, while winter was the period of the lowest densities, except for the month of December Fig. 5.

There is a clear evidence of this trend from the mean annual cycles that showed a regular pattern common to each station (Fig. 6): a phase of phytoplankton increase from March to September, more or less variable in abundance, length and timing of peaks, following a decrease and a new rapid increase in December, afterwards the lowest mean densities took place.

From the analysis of phytoplankton community composition, four groups were distinguished Table 1]: diatoms, dinoflagellates, cryptophyceans and a group named "other flagellates" including prasinophyceans, chrysophyceans, euglenophyceans, coccolithophorids and undetermined flagellates of uncertain taxonomic identification for their small size, generally $<15 \mu \mathrm{m}$.

Diatoms (mean density of $0.16 \times 10^{6}$ cells per 1 ) were relevant only during summer, particularly in st. 1 and in the Laguna di Levante Fig. 7, where they accounted for the highest peaks of total densities Fig. 5. These blooms were due to nanoplanktonic centric taxa (Chaetoceros tenuissimus Meunier, Chaetoceros simplex Paulsen, Thalassiosira spp., Skeletonema costatum (Greville) Cleve and an undetermined
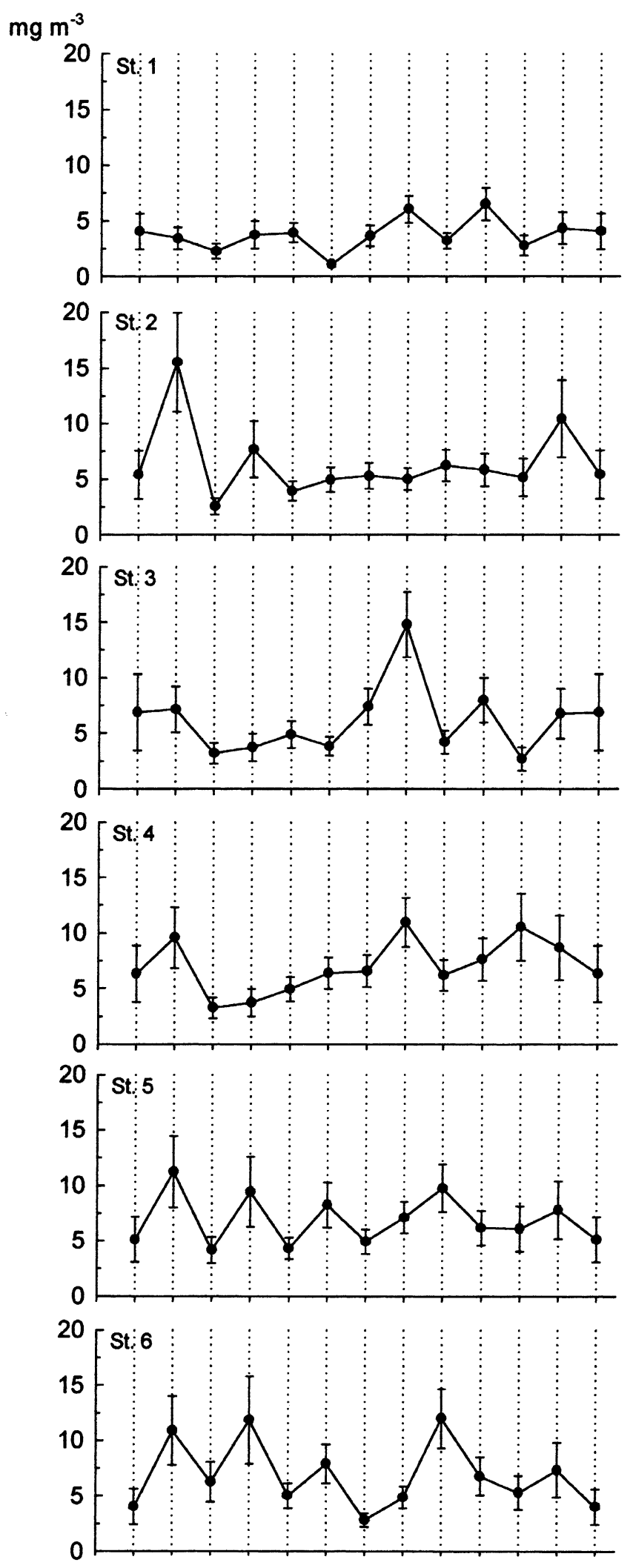

jan feb mar apr may jun jul augsept oct nov dec jan

Fig. 4. Chloropheopigment concentrations $\left(\mathrm{mg} \mathrm{m}^{-3}\right)$ in the six stations: monthly mean + S.E. 


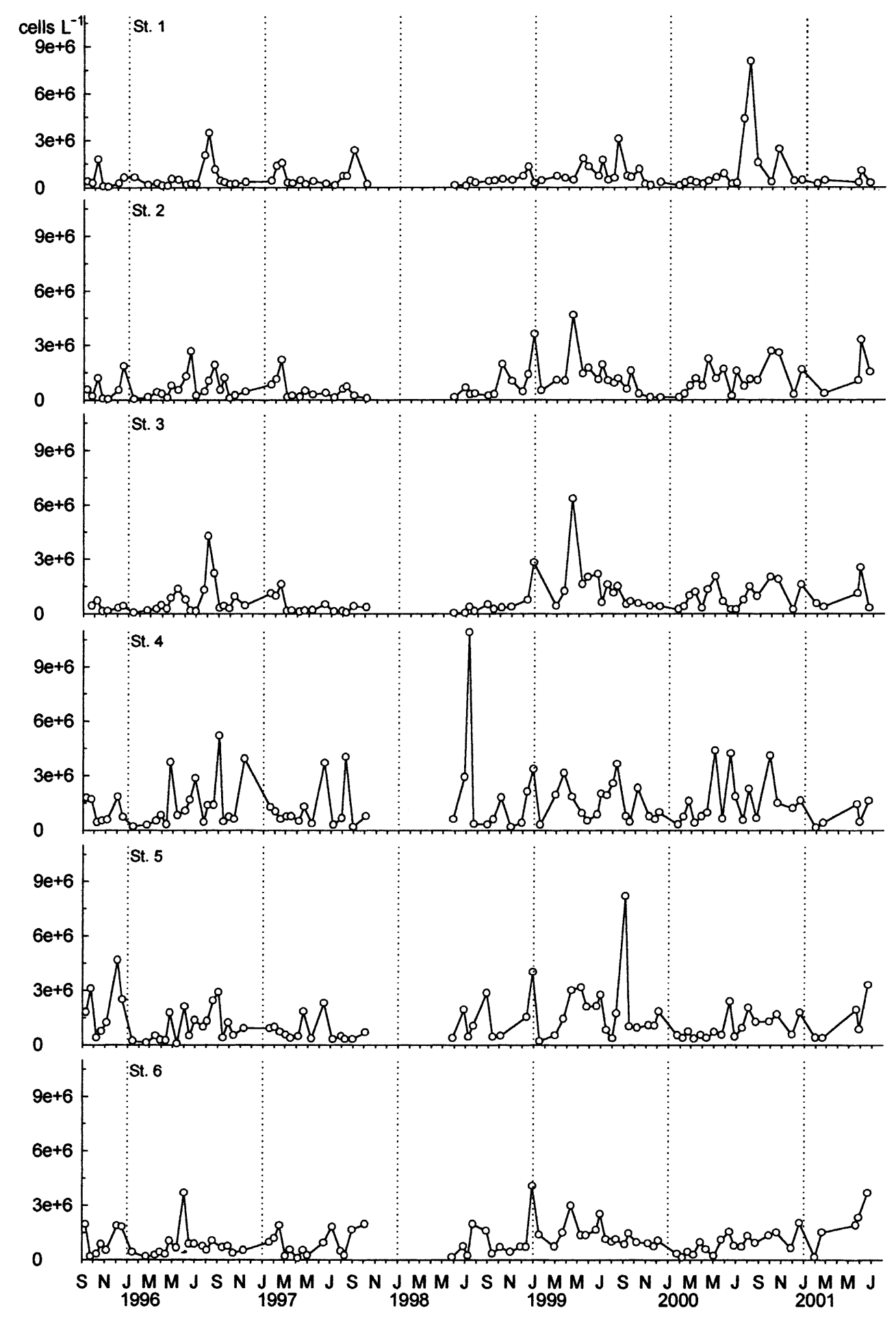

Fig. 5. Interannual variation of total phytoplankton densities (cells per 1) in the six stations.

form $\sim 6-7 \mu \mathrm{m}$ ), while during the other seasons a poor and diversified pennate diatoms assemblage prevailed, mainly with Cylindrotheca closterium (Ehr.) Lewin \& Reimann and many tichopelagic forms Table 1 .

Dinoflagellates did not show evident temporal variations (mean density $0.15 \times 10^{6}$ cells per l) with a slight increasing trend from summer to fall Fig. 7). The most abundant taxa were small thecate forms, as Heterocapsa sp. and undetermined Gymnodiniaceae spp. The presence of toxic dinoflagellates like Gymnodinium sanguineum Hirasaka and Dinophysis spp., more abundant in late summer and fall was observed.

Cryptophyceans were represented in five different forms, but only one of them, Cryptophycea sp. $12 \mu \mathrm{m}$ (cf. Crypto- 

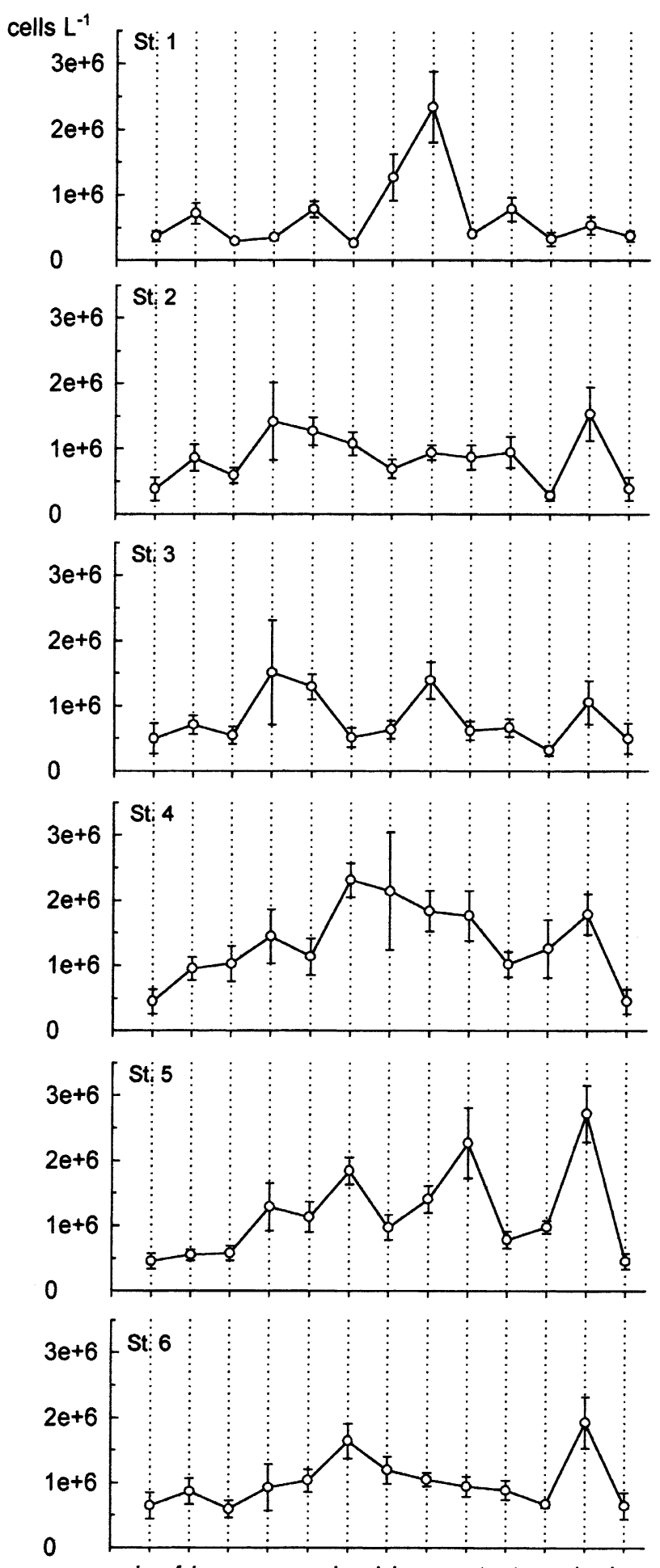

jan feb mar apr may jun jul augsept oct nov dec jan

Fig. 6. Total phytoplankton densities (cells per 1): monthly mean + S.E.

monas) was always the most abundant. They had the highest mean density with $0.49 \times 10^{6}$ cells per 1 , widespread in the whole Lagoon, the highest percentage of dominance from winter to spring and the minima in summer Fig. 7.

The other flagellates were an heterogeneous group, in which small and undetermined forms $<10 \mu \mathrm{m}$ and some prasinophyceans (probably Tetraselmis and Pyramimonas)
Table 1

List of the phytoplankton taxa founded in the Orbetello lagoon

\section{Centric diatoms}

Chaetoceros compressus Lauder

Chaetoceros simplex Paulsen

Chaetoceros tenuissimus Meunier

Chaetoceros spp. $<20 \mu \mathrm{m}$

Leptocylindrus danicus Cleve

Proboscia alata (Brightwell) Sündstrom

Rhizosolenia cf. pungens Cleve-Euler

Rhizosolenia cf. setigera Brightwell

Skeletonema costatum (Greville) Cleve

Thalassiosira spp.

Undetermined centric diatoms

Pennate diatoms

Achnantes spp.

Amphiprora spp.

Amphora spp.

Asterionellopsis glacialis (Castracane) Round

Bacillaria paxillifera (O.F. Müller) Hendey

Cocconeis scutellum Ehrenberg

Cocconeis spp.

Cylindrotheca closterium (Ehr.) Lewin \& Reimann

Diploneis cf. crabro Ehrenberg

Diploneis spp.

Eunotia sp.

Fragilaria spp.

Grammatophora spp.

Licmophora spp.

Mastogloia sp.

Navicula spp.

Nitzschia cf. acicularis W. Smith

Nitzschia longissima (Brébisson) Ralfs in Pritchard

Nitzschia spp.

Pleurosigma spp.

Striatella cf. unipunctata (Lyngbye) C.A. Agardh

Synedra spp.

Thalassionema nitzschioides (Grun.) Mereschkowsky

Thalassionema spp.

Thalassiothrix $\mathrm{sp}$.

Undetermined pennate diatoms

Dinoflagellates

Amphidinium spp.

Dinophysis caudata Saville-Kent

Dinophysis spp. (acuminata group)

Gonyaulax cf. scrippsae Kofoid

Gonyaulax spp.

Gymnodiniaceae spp.

Gymnodinium sanguineum Hirasaka

Gyrodinium spp.

Heterocapsa sp.

Oxytoxum cf. sceptrum (Stein) Schröder

Oxytoxum sp.

Oxytoxum variabile Schiller

Prorocentrum cf. dentatum Stein

Prorocentrum gracile Schütt

Prorocentrum micans Ehrenberg

Prorocentrum minimum (Pavillard) Schiller

Prorocentrum spp.

Prorocentrum triestinum Schiller

Protoperidinium quinquecorne (Abé) Balech 
Table 1

(continued)

Protoperidinium spp.

Scrippsiella sp.

Undetermined naked dinoflagellates

Undetermined thecate dinoflagellates

Cryptophyceans

Cryptophycea sp. 1 (cf. Cryptomonas)

Undetermined cryptophyceans

Other flagellates (including Coccolithophorids)

Alisphaera ordinata (Kamptner) Heimdal

Apedinella spinifera (Throndsen) Throndsen

Calycomonas sp

Coronosphaera mediterranea (Lohmann) Gaarder

Emiliania huxleyi (Lohmann) Hay \& Mohler

Euglena sp.

Eutreptia sp.

Eutreptiella sp.

Paulinella ovalis Wulff

Syracosphaera pulchra Halldall \& Markali

Undetermined flagellates $<10 \mu \mathrm{m}$

Undetermined flagellates $<20 \mu \mathrm{m}$

prevailed while coccolithophorids and the other taxa Table 1 were only occasionally present. They showed a more variable trend during the year and in the six stations Fig. 7 but were on average more abundant than diatoms and dinoflagellates (mean density $0.26 \times 10^{6}$ cells per 1 ) with some summer peak and a general increase in December Fig. 7.

Some of the highest blooms evidenced in Fig. 5 were due to the same species, as the undetermined centric diatom approximately 6-7 $\mu \mathrm{m}$ in August 1996 (st. 1, 3, 5), July 1997 (st. 4) and September 1999 (st. 5), the Cryptophycea sp. $12 \mu \mathrm{m}$, in some case together with an undetermined flagellate approximately $6 \mu \mathrm{m}$, in December 1995, 1996, 1998. In other cases there were single blooms never recurrent like Apedinella spinifera (Throndsen) Throndsen in June 1997 or Skeletonema costatum (Greville) Cleve in June 1996 at st. 4.

On the basis of the relative abundances of the four groups computed for each sample, the phytoplankton communities were classified and named as showed in Table 2 The types dominated by cryptophyceans represented the prevailing structure of phytoplankton community, both as single class ("C") and with another class ("Cx"). These types, in which cryptophyceans represent on average the 87 and $59 \%$ of the total phytoplankton densities, respectively, are recurrent in about half of the samples (Table 2. In order of importance, the types dominated by flagellates ("F" and "Fx") represented together the $13.7 \%$ of the samples and the "M" type, where the different groups had a more similar percentage of dominance, the $11.8 \%$ Table 2.

These communities followed a recognizable cycle in the different stations Fig. 7. The "C" type prevailed from January to spring, from summer to fall the differentiation increased, with the appearance of "B", "Dx", "Fx", "Bx" and "Cx" types. During fall the communities reached the highest differentiation with the dominance of the "M" type and a new
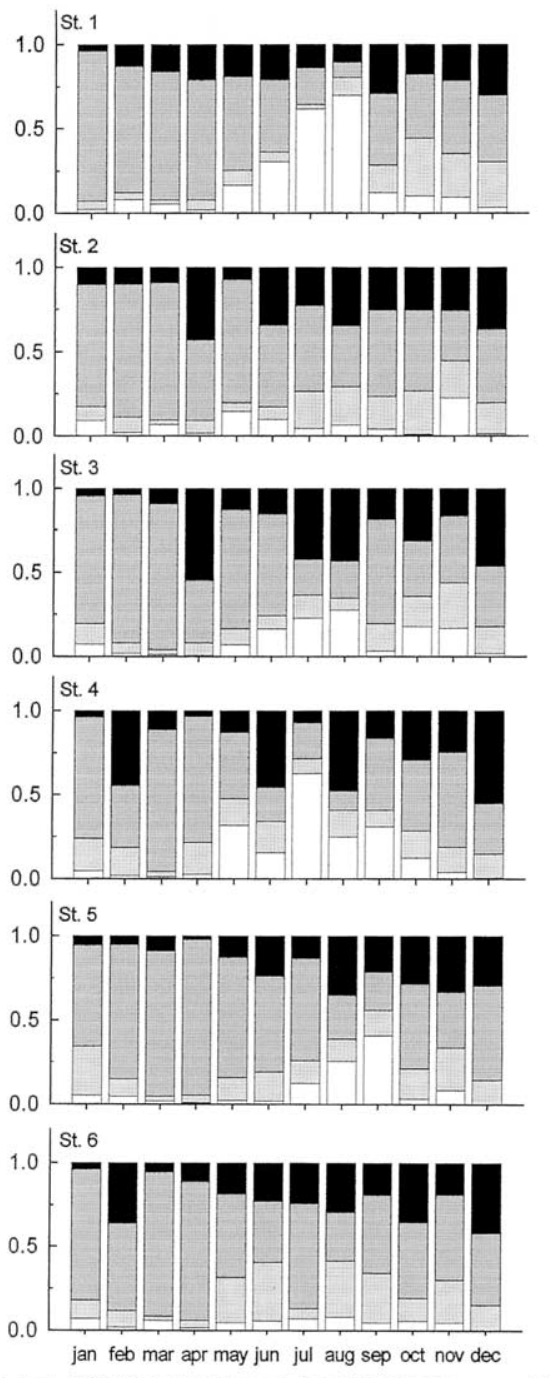

$\square$ Diatoms $\rightleftharpoons$ Dinoflagellates $\rightleftharpoons$ Cryptophyceans $=$ Other flagellates

Fig. 7. Phytoplankton composition: bars represents the relative abundances computed from the monthly means of the four groups.

change occurred in December when the rise of densities Fig. 6 corresponded to the presence of "CF" type.

The seasonal variation of phytoplankton diversity too showed oscillations at short time scale around a mean of 1.96 bit per cell, from minima lesser than 1 to maxima of 4.11 (Laguna di Ponente) and 3.88 bit per cell (Laguna di Levante). From the mean annual cycle for each site (Fig. 8) we can see that the phase of lower diversity covered the period from winter to spring, while from late spring an increase towards the maximum diversity in November was established. From the comparison of the annual mean evolution of diversity Fig. 8 with that of the community succession Fig. 7) it was evident that the lowest diversities during winter corresponded to the development of " $\mathrm{C}$ " type while in summer the other groups grew, with different pattern in the different sites: a dominance of " $B$ " in st. 1 and 4 , that accounted for their slight summer decreases of diversity and occurred later in st. 5, a less variable evolution in st. 2 and 6, where the relative abundance of dinoflagellates was higher, a 
Table 2

Classification on the basis of class dominances, denomination, percentage of occurrence and mean (arithmetic mean) Shannon diversity index (bit per cell) of the different phytoplankton communities $(\mathrm{C}=$ cryptophyceans, $\mathrm{B}=$ diatoms, $\mathrm{D}=$ dinoflagellates, $\mathrm{F}=$ other flagellates, $\mathrm{M}=$ mixed composition). For the sake of brevity the types named with two letters are cited in the text as $\mathrm{Cx}, \mathrm{Bx}, \mathrm{Dx}, \mathrm{Fx}$

\begin{tabular}{|c|c|c|c|c|}
\hline Dominant class & Other classes & Denomination & Percentage of occurrence $(\%)$ & Bit per cell \\
\hline \multirow[t]{4}{*}{$\geq 50 \%$} & No classes $\geq 20 \%$ & $\mathrm{C}$ & 34.1 & 1.26 \\
\hline & & $\mathrm{B}$ & 4.2 & 1.82 \\
\hline & & $\mathrm{D}$ & 1.3 & 1.81 \\
\hline & & $\mathrm{F}$ & 4.0 & 1.86 \\
\hline \multirow[t]{4}{*}{$\geq 40 \%$} & A second class $\geq 20 \%$ & $\mathrm{CB}, \mathrm{CD}, \mathrm{CF}(\mathrm{Cx})$ & 23.6 & 2.16 \\
\hline & & $\mathrm{BC}, \mathrm{BD}, \mathrm{BF}(\mathrm{Bx})$ & 4.4 & 2.52 \\
\hline & & $\mathrm{DB}, \mathrm{DC}, \mathrm{DF}(\mathrm{Dx})$ & 6.9 & 2.36 \\
\hline & & $\mathrm{FB}, \mathrm{FC}, \mathrm{FD}(\mathrm{Fx})$ & 9.7 & 2.49 \\
\hline No dominant class & Three or four classes $\geq 20 \%$ & $\mathrm{M}$ & 11.8 & 2.82 \\
\hline
\end{tabular}

variable presence of "Fx" types. In any case, there was evidence of the increase of diversity up to the highest values of November represented by the "M" type. At the end of the year the general decrease of diversity corresponded to the occurrence of "CF" or "FC" types. It can be emphasized that the minimum diversities occurred either during the monospecific blooms that characterized the highest densities Fig. 5 , or during the winter phase of the lowest densities with the striking dominance of cryptophyceans Fig. 7 .

From the comparison between nutrient concentrations Fig. 2, N/P ratio Fig. 3 and phytoplankton community characteristics Figs. 6-8, during the summer trophic conditions the most diversified community develops while in the winter ones mainly the community dominated by cryptophyceans with the lowest density and diversity occurred. The different types of community have a distinct distribution related to the contemporary N/P ratio in the waters Fig. 9 . The " $C$ " type established itself at the highest values of the ratio, reached in winter when the availability of DIP decreases. The other types occur in a relatively wide range of lower values of the ratio, occurring from late spring to fall.

\section{Conclusion}

Previous observations about phytoplankton community in the Orbetello lagoon are available from two seasonal cycle in 1975-1976 (De Angelis, 1978) and 1988-1989 (Vigliani, 1990) and from some bloom observations carried out from 1986 to 1989 (Tolomio and Lenzi, 1996).

Phytoplankton mean abundances appear to be increased from $1975-1976\left(0.58 \times 10^{6}\right.$ cells per 1$)$ to $1988-1989(0.88$ $\times 10^{6}$ cells per 1$)$ and to our survey $\left(1.06 \times 10^{6}\right.$ cells per 1$)$. Anyway neither massive and prolonged phytoplankton blooms nor distrophic crisis occurred during our sampling period. From this point of view it is possible to hypothesize an improvement of the environmental conditions of the Lagoon.

About the phytoplankton composition both De Angelis (1978) and Vigliani (1990) did not give information about the blooming species. The dominance of flagellates (De Angelis, 1978) and cryptophyceans (Vigliani, 1990), the relatively poor presence of other phytoplankton groups as diatoms, that prevail mainly close to the canals of Nassa and Ansedonia and the scarce number of taxa of relevant abundances were the main features. From the two cycles any evident pattern of variation either of cell densities or community was pointed out, probably for the limited sampling time. Tolomio and Lenzi (1996) reported quasi monospecific blooms of cryptophyceans in winter and Skeletonema costatum (Greville) Cleve in September and a late summer bloom of more heterogeneous composition.

From our survey, some attributes of the phytoplankton community are confirmed. Even if a relatively high number of taxa (a total of 181 observed taxa, many of which grouped in Table 1 only with genera denomination) was observed, only few of them had high number of individuals and were common to all the different sites of the lagoon. The nanoplanktonic fraction is the most abundant (Gymnodiniaceae spp., cryptophyceans, centric diatoms, small flagellates) with fast blooms. The communities characterized by the dominance of cryptophyceans and other flagellates are the most recurrent and widespread in all the sites of the Lagoon, while the diatoms mainly bloom in summer with few centric taxa, particularly at st. 1 and 4 where the sea-water influence produce smoothed variations of the environmental conditions, mainly temperature and salinity. Already De Angelis (1978) evidenced the greater species richness of these sites and this fact is highlighted by the slight higher mean diversity of st. 1 (2.15 bit per cell (in both cases)) and st. 4 (1.99 bit per cell per 1).

Also studies from other Mediterranean lagoons, like the Varano Lagoon facing the Adriatic Sea (Caroppo, 2000), a Center-Western Sardinia lagoon (Fiocca et al., 1996) or the Spanish Mar Menor (Gilabert, 2001) evidence that phytoplankton densities show sudden increase of a limited number of species and the highest values in summer and/or some peak in winter. Mainly flagellates belonging to different class (chlorophyceans, cryptophyceans, euglenophyceans) and summer diatom blooms characterize the phytoplankton composition.

Our relatively long time series give a good evidence that micro- and nanophytoplankton abundances, community succession and the resulting diversity changes, follow a seasonal cycle recognizable for the whole Lagoon despite the short 

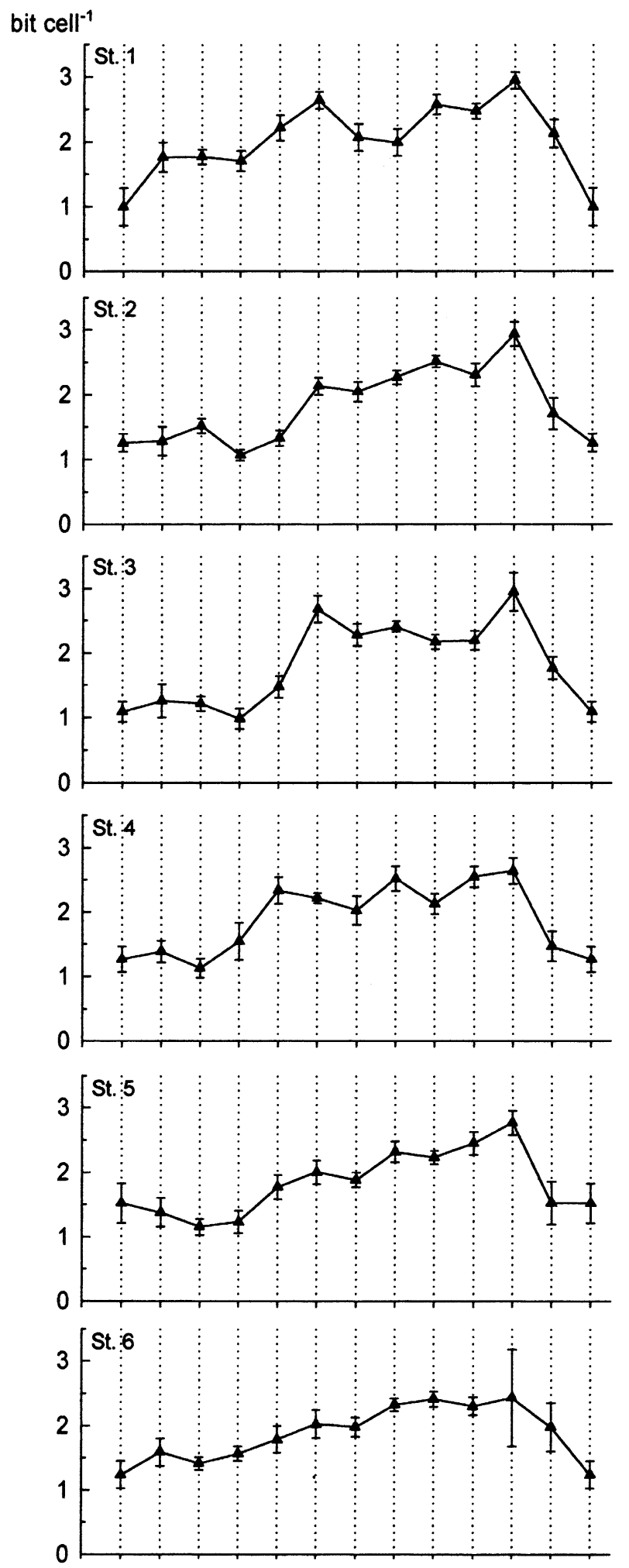

jan feb mar apr may jun jul augsept oct nov dec jan

Fig. 8. Phytoplankton diversity (bit per cell) in the six stations: monthly mean + S.E.

time scale variability. The higher variability of chloropheopigment cycles highlights these changes related to the environmental conditions, taking into account the physi-

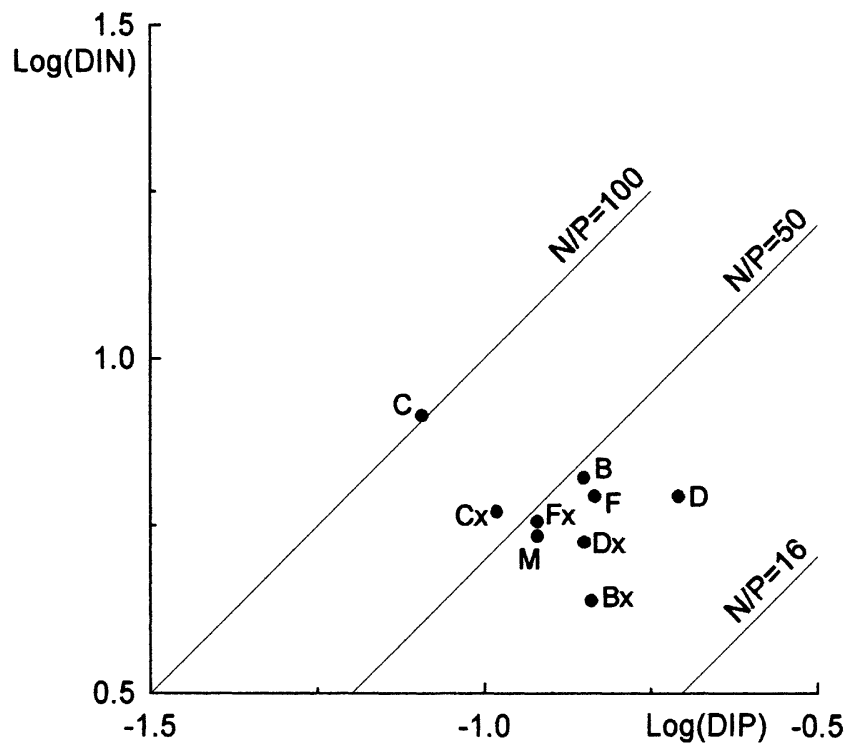

Fig. 9. Distribution of the different types of phytoplankton community on the basis of the mean $\log$ (DIN) and $\log$ (DIP) computed from all the samples with the same type of community. Denomination as in Table 2.

ological status of the cells and the presence of the picophytoplankton component, not evaluated with the Utermöhl analysis.

During the phytoplankton succession, cryptophyceans show their striking dominance in winter-spring, representing the community with minimum diversity, while from spring to fall more species of different phytoplankton classes co-occur with a variable relative importance in the different sites. Also in Mar Menor phytoplankton community reached the highest taxonomic diversification in fall (Gilabert, 2001).

The annual cycle of phytoplankton diversity in the Orbetello lagoon show a sharp seasonality. Some local differences have been appreciated, as already showed in st. 1 and 4 or in st. 6 in which the smoothed diversity changes were probably related to its more confined location. Nevertheless, the character of the diversity oscillation well reflects the modification of the community structure that changes from environmental conditions that support a more restricted group of organisms (cryptophyceans) towards conditions enhancing the community diversity. Although the presence of many small forms hard to recognize and the intraspecific variability of the taxa that could give an absolute underestimate of diversity, it is possible to consider this repeated seasonal trend of oscillation between lower and higher values as an actual characteristic of the phytoplankton community succession in the Orbetello lagoon.

The mutual DIN and DIP availability leads to a seasonal change of N/P ratio, high in winter and low in summer, with the same shape of variation but with much higher values of other lagoon waters (Fiocca et al., 1996). This factor seems to play an important role in determining the phytoplankton community succession, favouring or limiting the growth of the different groups. The winter conditions of lower salinity probably indirectly favours the dominance of crypto- 
phyceans, as well known from other researches (Jacques, 1969) while diatoms and dinoflagellates show their maximum growth during the summer when the DIP availability leads to the minima N/P ratios.

The nutrient pattern of availability and depletion seems very likely related to the release from sediments by means of the bacterial degradation of organic matter (Innamorati et al., 2000). Also the presence of macroalgae could contribute to the seasonality of nutrient availability: their growth contribute to the spring-summer DIN consumption as their following degradation to the summer DIP fast recycling and to the yearly storage of nitrogen in the sediments (Viaroli et al., 1992). As observed from a preliminary elaboration of meteorological data, the wind induced mixing and resuspension does not influence the seasonal restoration of the highest nutrient concentrations. Only high and prolonged wind speed seems to act during the periods of lower concentrations, during summer for DIN and winter for DIP (Innamorati, unpublished data).

The phytoplankton community structure-influenced by the nutrients availability - determines its specific diversity so that an indirect role of the nutrients in controlling the overall seasonal cycle of the diversity (high in summer, low in winter) can be hypothesized, therefore, oscillation between the two overall periods of maximum and minimum could be affected by other factors than N/P ratio.

The maxima of the diversity are reached in fall and in such transitional condition low densities and high equitability coexist. However, the summer rising trend of diversity corresponds to the development of more growing taxa, so that densities also increase, in winter the diversity is always low while the densities reach only a short, but yearly recurrent, December maxima.

From these considerations emerge the factors influencing density and diversity could be different or act in different way on the phytoplankton populations.

\section{Acknowledgements}

The authors thank Dr. Daniele Bisignano, Dr. Patrizia Cartei, Dr. Alessandro Iozzelli, Dr. Sandra Nistri, who performed part of the field sampling and microscopic analysis. This study is an elaboration of the results of the researches supported by: Commissario Straordinario per il Risanamento della Laguna di Orbetello (grant n. 2380 P.C.M./F.P.C.M. 31/03/94), Ministero dell'Università $e$ della Ricerca Scientifica e Tecnologica (Programmi di Ricerca Scientifica di Rilevante Interesse Nazionale, 1997-1999 and 1999-2001 research grants) and Ministero delle Politiche Agricole e Forestali (IV Piano Triennale della Pesca e dell'Acquacoltura, 1998-2001 research grant).

\section{References}

Butcher, R.W., 1967. An introductory account of the smaller algae of British coastal waters. Part IV. Cryptophyceae. Fish. Invest. Ser. IV. H.M.S.O., London.

Caroppo, C., 2000. The contribution of picophytoplankton to community structure in a Mediterranean brackish environment. J. Plankton Res. 22, 381-397.

Carrada, G.C., Fresi, E., 1988. Le lagune salmastre costiere. Alcune riflessioni sui problemi e sui metodi. In: Carrada, G.C., Cicogna, F., Fresi, E. (Eds.), Le lagune costiere: ricerca e gestione. CLEM, Massa Lubrense (Napoli), pp. 35-56.

Cartei, P., Innamorati, M., Melillo, C., 1998. Omeostasi trofica modulata dal mare ed ipertrofia autoctona lagunare. Biol. Mar. Medit. 5, 41-46.

Cupp, E., 1977. Marine plankton diatoms of the West Coast of North America. Otto Koeltz Science Publishers, D-624 Koenigstein, W-Germany.

De Angelis, C.M., 1978. Plancton. In: Cognetti, G., De Fraja Frangipane, E. (Eds.), (a cura di) Risanamento e protezione dell'ambiente idrobiologico delle lagune di Orbetello. Regione Toscana, Comune di Orbetello, pp. 53-58.

Fiocca, F., Lugliè, A., Sechi, N., 1996. The phytoplankton of S'Ena Arrubia Lagoon (Centre-Western Sardinia) between 1990 and 1995. Giorn. Bot. It. 130, 1016-1031.

Gilabert, J., 2001. Seasonal plankton dynamics in a Mediterranean hypersaline coastal lagoon: the Mar Menor. J. Plankton Res. 23, 207-217.

Hasle, G.R., Syvertsen, E.E., 1997. Marine Diatoms. In: Tomas, C.R. (Ed.), Identifying Marine Phytoplankton. Academic Press, San Diego, pp. 5-386.

Heimdal, B.R., 1997. Modern Coccolithophorids. In: Tomas, C.R. (Ed.), Identifying Marine Phytoplankton. Academic Press, San Diego, pp. 731-834.

Innamorati, M., 1998. La Laguna di Orbetello: risanamento e gestione conservativa. Biol. Mar. Med. 5, 1352-1361.

Innamorati, M., Ferrari, I., Marino, D., Ribera D’Alcalà, M., 1990. Metodi nell'ecologia del plancton marino. Nova Thalassia 11, 372.

Innamorati, M., Massi, L., Lazzara, L., Cartei, P., 1994. Biomassa fitoplanctonica e proprietà ottiche del mare. Biol. Mar. Medit. 1, 83-88.

Innamorati, M., Melillo, C., Giovanardi, F., 2000. Rilascio bentonico dei nutrienti nella Laguna di Orbetello. Biol. Mar. Medit. 7, 130-139.

Innamorati, M., Melillo, C., Massi, L., 2001. La gestione idraulica e ittica, gli apporti antropici e naturali per la degradazione della Laguna di Orbetello. Biol. Mar. Medit. 8, 452-461.

Innamorati, M., Nuccio, C., Massi, L., Biondi, N., Lazzara, L., 1996. La diversità fitoplanctonica dell'Adriatico e del Tirreno. Biol. Mar. Medit. 3, 21-25.

Jacques, G., 1969. Aspects quantitatifs du phytoplankton de Banyuls-surmer (Golfe du Lion). II. Cycle del flagellés nanoplanctoniques (juin 1965-juin 1967). Vie et Milieu XX, 17-33.

Jeffrey, S.W., Humphrey, G.F., 1975. New spectrophotometric equations for determining chlorophylls $a, b, \mathrm{c}_{1}$ and $\mathrm{c}_{2}$ in higher plants, algae and natural phytoplankton. Biochem. Physiol. Pflanzen 167, 191-194.

Lenzi, M., 1992. Experiences for the management of Orbetello lagoon: eutrophication and fishing. Sci. Total Environ. (Suppl. 1992), 1189-1198.

Schiller, J., 1931-1933. Dinoflagellatae (Peridineae). Monographischer Behaundlung. In: Rabenhorst, L. (Ed.), Kriptogamen-Flora von Deutschland, Osterreich und der Schweiz. Band X, Teil 1. Akademische Verlag, Leipzig.

Schiller, J., 1935-1937. Dinoflagellatae (Peridineae). Monographischer Behaundlung. In: Rabenhorst, L. (Ed.), Kriptogamen-Flora von Deutschland, Osterreich und der Schweiz. Band X, Teil 2. Akademische Verlag, Leipzig. 
Sournia, A., 1986. Introduction, Cyanophycèes, Dictyochophycèes, Dinophycèes et Raphidophycèes. In: Sournia, A. (Ed.), Atlas du phytoplancton marin, Vol. I. Ed. CNRS, Paris.

Steidinger, K., Tangen, K., 1997. Dinoflagellates. In: Tomas, C.R. (Ed.), Identifying Marine Phytoplankton. Academic Press, San Diego, pp. 387-584.

Throndsen, J., 1997. The planktonic Marine Flagellates. In: Tomas, C.R. (Ed.), Identifying Marine Phytoplankton. Academic Press, San Diego, pp. 591-730.

Tolomio, C., Lenzi, M., 1996. « Eaux colorées » dans les lagunes d'Orbetello et de Burano (Mer Tyrrhénienne du Nord) de 1986 à 1989. Vie Milieu 46, 25-37.
Viaroli, P., Pugnetti, A., Ferrari, I., 1992. Ulva rigida growth and decomposition processes and related effects on nitrogen and phosphorus cycles in a coastal lagoon (Sacca di Goro, Po River Delta). In: Colombo, G., Ferrari, I., Ceccherelli, V.U., Rossi, R. (Eds.), Marine Eutrophication and population dynamics. Olse \& Olsen Fredensborg, pp. 77-84.

Vigliani, M.S., 1990. Condizioni trofiche della Laguna di Orbetello negli anni 1988-1989. Thesis in Biological Science, Faculty of Science, University of Milano.

Zingone, A., Honsell, G., Marino, D., Montresor, M., Socal, G., 1990. Fitoplancton. In: Inamorati, M., Ferrari, I., Marino, D., Ribera D'Alcalà, M. (Eds.), Metodi nell'ecologia del plancton marino, vol. 11. Nova Thalassia, pp. 183-198. 